\title{
Dog bite and injury prevention-analysis, critical review, and research agenda
}

\author{
J Ozanne-Smith, K Ashby, V Z Stathakis
}

\begin{abstract}
Objectives-To analyze Australian dog bite injury data and make international comparisons; to review risk and protective factors relating to the $\mathrm{dog}$, injured person, and environment; and to recommend action for prevention and research.

Methods-Australian dog bite injury data, complemented by detailed Victorian and regional data from routine health records and vital statistics, were analyzed to determine incidence, severity, nature, circumstances, and trends. International comparison data were extracted from published reports. Risk and protective factor studies were selected for review from electronic and bibliographic searches where data were recent, sample sizes substantial, and bias limited.

Results-The Australian dog bite death rate $(0.004 / 100000)$ is lower than both the United States (0.05-0.07/100 000) and Canadian rates $(0.007 / 100000)$. Victorian hospitalized trend rates were stable between 1987 and 1998, but there was a decline for children $<5$ years $(p=0.019)$ corresponding with a reduction in dog ownership. Children 0-4 years have the highest rate of serious injury, particularly facial. Adults have longer hospitalizations, most frequently for upper extremity injury. Risk factors include: child, males, households with dogs, certain breeds, male dogs, home location, and leashed dog.

Conclusions-Dog bite rates are high and it may therefore be assumed that current preventative interventions are inadequate. Responsible dog ownership, including separating young children from dogs, avoiding high risk dogs, neutering, regulatory enforcement, and standardized monitoring of bite rates are required. Controlled investigations of further risk and protective factors, and validated methods of breed identification, are needed.

(Injury Prevention 2001;7:321-326)
\end{abstract}

Monash University Centre, PO Box 70A, Monash University, Victoria 3800,

Australia

J Ozanne-Smith

K Ashby

V Z Stathakis

Correspondence to: Professor Ozanne-Smith joan.ozanne-smith@ general.monash.edu.au

Keywords: dog bite; risk factors; epidemiology; research

Dog bite has been identified for many years as a source of potentially serious but infrequently fatal injury. It is only since the advent of computerized injury data that it has become possible to describe fully the true dimensions and nature of this public health problem. The availability of a specific mechanism of injury code (E code 906.0) for dog bite in the International Classification of Diseases (ICD) ${ }^{1}$ considerably enhances the possibilities for describing and monitoring deaths and hospitalizations and for making international comparisons.

We analyzed Australian data on dog bite injury and reviewed the international comparative data. We also reviewed risk and protective factors relating to the dog, the injured person, and the environment and the implications for prevention. From these analyses and review we established a research agenda for dog bite prevention.

\section{Method}

Australian dog bite injury data were obtained from the National Injury Surveillance Unit at Flinders University, which holds national death and hospitalization data. Data for the state of Victoria (estimated population 4.7 million) were analyzed to complement the national data, particularly with respect to secular trends, using a $\log$ linear Poisson regression model, and circumstances of injury, including the identification of potential risk factors. Sources were the Victorian Inpatient Minimum Database (hospital admissions), the Victorian Injury Surveillance System (emergency department presentations), and the Victorian Coroner's Facilitation System (coronial data). Each of these data sources is described in detail elsewhere. ${ }^{2}{ }^{3}$ The availability of data at varying levels of severity allows for a depth of understanding of dog bite not often achieved elsewhere. A logistical algorithm was used to exclude readmissions and transferred patients. International comparative data were extracted from published literature and from the internet. $^{45}$

Literature reviews used a variety of sources to identify risk factor data, including exposure. Electronic searches were conducted using Medline, Cinahl, and Sociofile. Bibliographic searches were based on articles retrieved from the computerized searches.

\section{Results}

Weiss et al report United States (US) rate ratio data ${ }^{6}$ derived from dog bite rates and national estimates based on a 1992 to 1994 national probabilistic survey of emergency department treated cases and official death reports. For each US dog bite fatality, there are an estimated 670 hospitalizations and 16000 emergency department visits. 
Table 1 Comparison of reported national/international dog bite rates by severity (rates/100 000)

\begin{tabular}{|c|c|c|c|c|c|c|}
\hline Country & Period & Death rate & $\begin{array}{l}\text { Hospital } \\
\text { admission rate }\end{array}$ & $\begin{array}{l}\text { Emergency } \\
\text { department } \\
\text { presentation rate }\end{array}$ & $\begin{array}{l}\text { All medically } \\
\text { treated rate }\end{array}$ & Total dog bite rate \\
\hline Australia & $1995 / 96$ & 0.004 & 7.7 & & & \\
\hline Adelaide $^{26}$ & Jan 1990-July 1993 & & & 73 & & \\
\hline $\begin{array}{l}\text { Latrobe Valley }^{11} \\
\text { (rural Victoria) }\end{array}$ & $1994 / 95$ & & & 151 & 263 & \\
\hline \multirow[t]{2}{*}{ Canada ${ }^{\star}$} & 1994-96 & & 2.6 & & & \\
\hline & $1987-97$ & 0.007 & & & & \\
\hline Guelph $^{34}$ & $1986-87$ & & & & & $\begin{array}{l}160 \text { (reported to health unit for review } \\
\text { and police complaints reports) }\end{array}$ \\
\hline \multicolumn{7}{|r|}{ 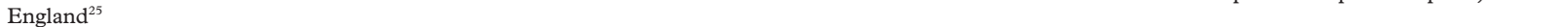 } \\
\hline Salisbury: high SES & & & & 150 & & \\
\hline Thanet: low SES & & & & 300 & & \\
\hline Netherlands $^{35}$ & $1992-96$ & & & 78 & & \\
\hline New Zealand ${ }^{24}$ & 1988 & & 4.8 & & & \\
\hline Dunedin & 1989-90 & & & 175 & & \\
\hline Hamilton & 1988 & & & 173 & & \\
\hline Lower Hutt & 1990 & & & 85 & & \\
\hline \multirow[t]{3}{*}{ United States $^{6730}$} & $1992-94$ & & & 129 & & 1800 (national telephone survey) \\
\hline & $1995-96$ & $0.05-0.07$ & & & & \\
\hline & 1994 & & & & 300 & \\
\hline Pittsburgh $^{36}$ & 1993 & & & & & 589 (animal control and police reports) \\
\hline
\end{tabular}

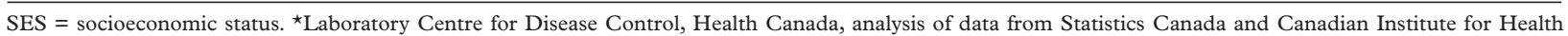
Information, unpublished results.

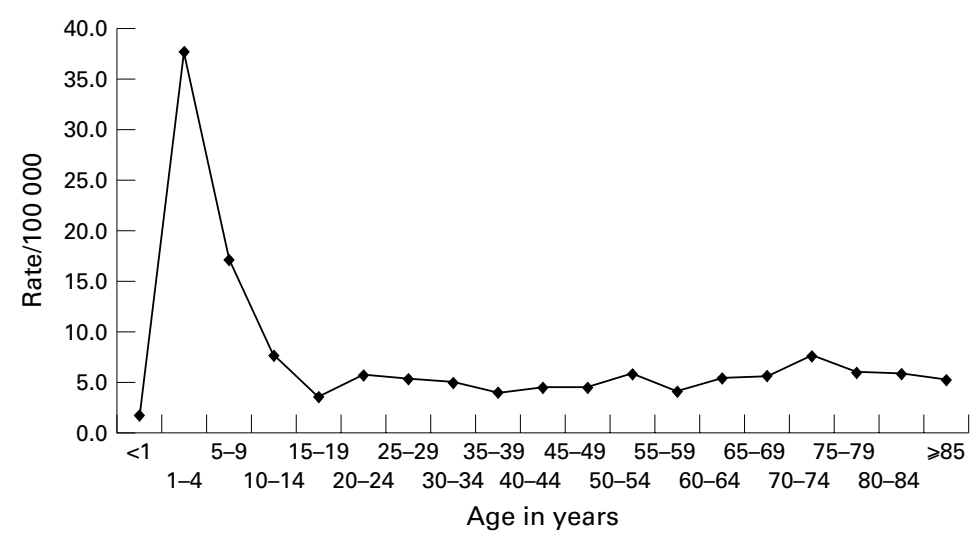

Figure 1 Dog bite hospitalization rates per 100000 by age group, Australia, fuly 1995 to Fune 1996. ${ }^{9}$ unauthorized access to a fenced yard or yard with leashed dogs; and dog escaping enclosure or restraint. ${ }^{8}$ Of the 199 US dog bite fatalities for which breed is known, pure breed pit bull and pit bull cross breeds were most frequently involved, followed by Rottweiler and Rottweiler cross breeds, and German shepherd and German shepherd cross breeds. Other identified high risk pure breeds included husky, Alaskan malamute, Doberman, chow-chow, Great Dane, St Bernard, and Akita.

HOSPITAL ADMISSIONS

One complete year (July 1995 to June 1996) of hospital admission data was available for all Australian states and territories. The national hospitalization rate was $7.7 / 100000$. The distribution of hospitalized dog bite victims by age group is shown for Australia in fig $1 .{ }^{9}$ Clearly, the highest risk is in the 1-4 years age group, followed by 5-9 year olds.

Data from elsewhere show quite similar patterns. Hospital admission rates are shown in table 1 . The trend for all age hospitalized dog bite in Victoria, Australia showed no overall reduction for 1987-88 to 1997-98. However, a significant downward trend for the $0-4$ year age group since $1993-94(p=0.019)$ is evident. National records over this period are not available.

Length of stay in hospital is taken as a proxy for severity. In Australia, July 1993 to June 1996, the average length of stay increased with the age of the victim. The majority of child admissions were under two days, while after 35 years, the majority, and an increasing proportion with age, were admitted for longer periods. Of victims aged over $75,47 \%$ were hospitalised for eight or more days.

EMERGENCY DEPARTMENT PRESENTATIONS

Emergency department presentations to 25

Victorian hospitals during 1996 and 1997 showed a different pattern by age group compared with admitted cases. Of the 2439 cases for which information was complete, $11.5 \%$ were admitted. Although children aged 0-9 represented $56.8 \%$ of admissions, this age owner's property $(70 \%)^{7}$; certain dog breeds; history of aggression; sleeping infant; child's 
Table 2 Risk factors for dog bite injury: place factors

\begin{tabular}{|c|c|c|c|c|c|c|}
\hline Source & Study design & Home location & Victim's home & Other home & Dog's home & Public places \\
\hline Ashby, $1996^{10}$ (Australia) & $\begin{array}{l}\text { ED surveillance, } \\
n=1916\end{array}$ & $\begin{array}{l}66 \% \text { of child, } 40 \% \text { of } \\
\text { adult cases where } \\
\text { location specified }\end{array}$ & $\begin{array}{l}32 \% \text { of child, } 34 \% \text { of } \\
\text { adult cases where } \\
\text { location specified }\end{array}$ & $\begin{array}{l}34 \% \text { of child, } 6 \% \text { of } \\
\text { adult cases where } \\
\text { location specified }\end{array}$ & & $\begin{array}{l}19 \% \text { of child, } 38 \% \\
\text { of adult cases } \\
\text { where location } \\
\text { specified }\end{array}$ \\
\hline $\begin{array}{l}\text { Flores et al, } 1997^{12} \\
\quad \text { (Canada) }\end{array}$ & $\begin{array}{l}\text { ED surveillance, } \\
\text { telephone follow up, } \\
n=385\end{array}$ & $78 \%$ & $40 \%$ & $38 \%$ & & \\
\hline $\begin{array}{l}\text { Shewell and Nancarrow, } \\
1991^{38}(\mathrm{UK})\end{array}$ & $\begin{array}{l}\text { Case series in plastic } \\
\text { surgery practice, } n=146\end{array}$ & & & & $85 \%$ & \\
\hline $\begin{array}{l}\text { South Australian Health } \\
\text { Commission } 1990^{33} \\
\text { (Australia) }\end{array}$ & $\begin{array}{l}\text { ED surveillance } \\
\text { children } 0-12 \text { years, } \\
\text { registry of Adelaide } \\
\text { dogs }\end{array}$ & & & & & $25 \%$ \\
\hline
\end{tabular}

group accounted for only $24.9 \%$ of nonadmitted emergency department cases.

A previous surveillance collection of seven Victorian public hospital emergency departments between 1988 and 1996 provided details of location of the injury event, body part injured, and circumstances of injury for almost 2000 cases of dog bite. ${ }^{10}$ For children under 15 years of age $66 \%$ (1331 cases) occurred at their own home or homes at which they were visitors. Although public places contributed only $19 \%$ of child cases, they accounted for $38 \%$ of the 585 adult cases. ${ }^{10}$

The body region affected shows different patterns for children and adults. The face and scalp represent $51 \%$ of bites to children in Victorian emergency department data and $82 \%$ of admitted cases, ${ }^{10}$ while $50 \%$ of adult bites presented to emergency departments were to the upper extremity.

Comparative rates of emergency department and medically treated (hospitalized, emergency department and general practitioner visits) dog bite are shown in table $1 .{ }^{11}$ The reported rates are of the same order of magnitude, in part a function of the large number of dog bite cases, though different data collection methods were used.

\section{EXPOSURE}

Clearly, the general population is not a specific measure of exposure to dog bite. Dog ownership by household is identified by many studies as a risk factor (table 2). ${ }^{12}{ }^{12}$ A 1992 survey of a representative sample of 4000 Melbourne households found that $33.5 \%$ of all households, $34.8 \%$ of households with children under 5 years, and $22.4 \%$ of households where a usual resident was 60 years or older, owned dogs. ${ }^{13}$ A repeat survey in 1998 found similar total household ownership of dogs $(34.6 \%)$, but a reduction in dog ownership in households with children under 5 years $(30.8 \%) .{ }^{14}$ Urban dog ownership by household (34.6\%) was lower than rural $(49.7 \%) .{ }^{14}$

Similarly, Australian telephone surveys of dog ownership, undertaken in 1994 and 1996, of 1011 and 12041 respondents respectively, ${ }^{15}{ }^{16}$ estimated a national dog population of 3.9 million with $42 \%$ of Australian households owning an average of 1.5 dogs. The 1994 survey also reported a 1:1 male to female dog ratio and $77 \%$ of dogs in the small to medium size range. ${ }^{15}$
A 1998 Victorian study ${ }^{17}$ that surveyed 78 Victorian municipalities to identify and measure the level of enforcement of the Domestic Animals (Feral and Nuisance) Act $1994,{ }^{18}$ also collected dog population data. More than $75 \%$ of the 34 respondent municipalities kept computerized data on registrations and infringements. As was found in the household survey the rate of registered dogs per 100 dwellings was significantly higher in rural municipalities (49.2/100 dwellings, 95\% confidence interval (CI) 43.4 to 55.0$)$ than in metropolitan municipalities (30.1/100 dwellings, 95\% CI 20.7 to 39.5$)(\mathrm{p}<0.01) .{ }^{14}$ Rural municipalities also recorded a significantly greater number of bites, rushes (dog rushing at victim), and dogs destroyed per 1000 registered dogs than metropolitan areas.

The 1992 Melbourne rate of dog ownership was similar to the 1991 US figure-36.5\% of households. The US dog population for that year was estimated at 53.5 million. ${ }^{19}$

DOG BREED

Caution should be exercised in interpreting breed data with regard to both dog bite (numerator) and dog population (denominator) data. ${ }^{20}$ Of households with dogs in the 1992 Melbourne household survey, $41.2 \%$ had pure breed and $58.8 \%$ cross breed dogs (154.7/100 000 and 220.7/100 000 households, respectively). ${ }^{13}$ Identification by breed proved unreliable, however, because of the uncertainty of breed assignment by owners and interviewers, particularly for cross breeds. Importantly, the term "pit bull" appears to be used for several breeds including the bull terrier, American Staffordshire bull terrier (also known as American pit bull terrier), and Staffordshire bull terrier. Confusion may be perpetuated by the media misinforming the public regarding dog breed..$^{22} 23$

RISK FACTORS

Our data analyses and literature review identified a number of consistently reported risk factors for non-fatal dog bite. However, only one case-control study was identified to support the associations found in a number of large case series. ${ }^{19}$

Risk factors relating to the place, the victim, and the dog are reported in tables 2, 3, and 4 respectively. Major risk factors identified in Australian and overseas studies include: children, especially under 5 years; male victims; 
Table 3 Risk factors for dog bite injury: person factors

\begin{tabular}{|c|c|c|c|c|c|}
\hline Source and date & Study design & $\begin{array}{l}\text { Children over- } \\
\text { represented }\end{array}$ & $\begin{array}{l}\text { Males over- } \\
\text { represented }\end{array}$ & Body part injured & $\begin{array}{l}\text { Victim known } \\
\text { to dog }\end{array}$ \\
\hline Ashby, $1996^{10}$ (Australia) & ED surveillance, $n=1916$ & Yes & Yes & $\begin{array}{l}51 \% \text { child face } / \text { head; } \\
33 \% \text { adults hand }\end{array}$ & \\
\hline Flores et al, $1997^{12}$ (Canada) & ED surveillance, telephone follow up, $n=385$ & Yes & Yes & $\begin{array}{l}74 \% 1-4 \text { years face } / \text { head } \\
68 \% \text { adults arms/legs }\end{array}$ & $71.2 \%$ \\
\hline Gerschman et al, $1994^{19}$ (US) & Case-control study non-household members, $n=178$ pairs & Yes & Yes & & \\
\hline Jarrett, $1991^{37}$ (UK) & Case series in ED & Yes & & & \\
\hline $\begin{array}{l}\text { Shewell and Nancarrow, } 1991^{38} \\
\text { (UK) }\end{array}$ & Case series in plastic surgery practice $(1982-89), n=146$ & Yes & No & & \\
\hline $\begin{array}{l}\text { Patrick and O'Rourke, } 1998^{28} \\
\text { (US) }\end{array}$ & $\begin{array}{l}\text { Random sample of animal control surveillance data, El } \\
\text { Paso, Texas, } n=300\end{array}$ & Yes & Yes & & \\
\hline Avner and Baker, $1991^{39}$ (US) & Case series of children attending hospital, $n=168$ & & Yes & & $77 \%$ \\
\hline Thompson, $1997^{26}$ (Australia) & $\begin{array}{l}\text { ED surveillance, } n=356 \text { (dog attacks) and population } \\
\text { survey, } n=3093\end{array}$ & Yes & Yes & $\begin{array}{l}90 \% \text { child admissions } \\
\text { head/face }\end{array}$ & \\
\hline
\end{tabular}

$\mathrm{ED}=$ emergency department.

Table 4 Risk factors for dog bite injury: dog factors

\begin{tabular}{|c|c|c|c|c|c|c|c|}
\hline Source & Study design & Dog gender & Dog breed & $\begin{array}{l}\text { Over-representation } \\
\text { of breed }\end{array}$ & $\begin{array}{l}\text { Interaction before } \\
\text { attack }\end{array}$ & $\begin{array}{l}\text { Unprovoked } \\
\text { attack }\end{array}$ & $\begin{array}{l}\text { Previous } \\
\text { history of } \\
\text { biting }\end{array}$ \\
\hline $\begin{array}{l}\text { Ashby, } 1996^{10} \\
\text { (Australia) }\end{array}$ & $\begin{array}{l}\text { ED surveillance, } \\
n=1916\end{array}$ & & $\begin{array}{l}\text { German shepherd, } \\
\text { bull terrier, heeler, } \\
\text { Rottweiler }\end{array}$ & & $\begin{array}{l}\text { Playing: } 17 \% \\
\text { Petting: } 10 \% \\
\text { Feeding: } 5 \%\end{array}$ & & \\
\hline $\begin{array}{l}\text { Flores et al, } 1997^{12} \\
\quad \text { (Canada) }\end{array}$ & $\begin{array}{l}\text { ED surveillance, } \\
\text { telephone follow } \\
\text { up, } n=385\end{array}$ & $73 \%$ male & $\begin{array}{l}\text { German shepherd, } \\
\text { cocker spaniel, } \\
\text { Rottweiler, golden } \\
\text { retriever }\end{array}$ & & $\begin{array}{l}\text { Ordinary } \\
\text { interaction: } 38 \% \\
\text { Teasing: } 33 \% \\
\text { No interaction: } \\
29 \%\end{array}$ & $29 \%$ & $\begin{array}{l}72 \% \text {, no } \\
\text { previous } \\
\text { history of } \\
\text { biting }\end{array}$ \\
\hline $\begin{array}{l}\text { Gerschman et al, } \\
1994^{19} \text { (US) }\end{array}$ & $\begin{array}{l}\text { Case-control study, } \\
\text { non-household } \\
\text { members, } n=178 \\
\text { pairs }\end{array}$ & $\begin{array}{l}\text { Male OR } 6.2(2.5 \\
\text { to } 15.1)\end{array}$ & & $\begin{array}{l}\text { German shepherd } \\
\text { OR } 16.4 \text { ( } 3.8 \text { to } \\
71.4) \\
\text { Chow-chow OR } \\
4.0(1.2 \text { to } 13.7)\end{array}$ & & & \\
\hline $\begin{array}{l}\text { Shewell and } \\
\text { Nancarrow, } 1991^{38} \\
\text { (UK) }\end{array}$ & $\begin{array}{l}\text { Case series in } \\
\text { plastic surgery } \\
\text { practice, } n=146\end{array}$ & $\begin{array}{l}85 \% \text { male (of } 96 \\
\text { cases) }\end{array}$ & $\begin{array}{l}\text { Staffordshire bull } \\
\text { terrier, Jack Russell }\end{array}$ & & $\begin{array}{l}\text { Playing: } 12 \% \\
\text { Petting: } 13 \% \\
\text { Waking: } 15 \%\end{array}$ & $42 \%$ & \\
\hline $\begin{array}{l}\text { Greenhalgh, et al, } \\
1991^{40} \text { (Australia) }\end{array}$ & $\begin{array}{l}\text { ED case series, } \\
\text { children, } n=159\end{array}$ & & & German shepherd & & & Uncommon \\
\hline $\begin{array}{l}\text { Avner and Baker, } \\
1989^{39} \text { (US) }\end{array}$ & $\begin{array}{l}\text { Case series of child } \\
\text { hospital } \\
\text { attendances, } n=168\end{array}$ & & $\begin{array}{l}\text { German shepherd } \\
20.8 \% \text {, pit bull } \\
19.6 \%\end{array}$ & & $46 \%$ provoked & $\begin{array}{l}\text { Significantly } \\
\text { more pit bull } \\
\text { terrier attacks } \\
\text { unprovoked }\end{array}$ & \\
\hline $\begin{array}{l}\text { Patrick and O'Rourke, } \\
1998^{28} \text { (US) }\end{array}$ & $\begin{array}{l}\text { Random sample of } \\
\text { animal control } \\
\text { surveillance data, } \\
n=300\end{array}$ & & & & $\begin{array}{l}50 \% \text { provoked in } \\
\text { children }<5 \text { years, } \\
\text { significantly more } \\
\text { likely to provoke } \\
\text { than older children }\end{array}$ & & \\
\hline $\begin{array}{l}\text { Thompson, } 1997^{26} \\
\text { (Australia) }\end{array}$ & $\begin{array}{l}\text { ED surveillance, } \\
\mathrm{n}=356, \text { population } \\
\text { survey, } \mathrm{n}=3093\end{array}$ & & $\begin{array}{l}\text { German shepherd, } \\
\text { pit bull terrier, } \\
\text { blue/red heeler, } \\
\text { Doberman, } \\
\text { Rottweiler }\end{array}$ & $\begin{array}{l}\text { All } 4-5 \text { times } \\
\text { higher frequency } \\
\text { than other breeds }\end{array}$ & & & \\
\hline $\begin{array}{l}\text { South Australian } \\
\text { Health Commission } \\
1990^{33} \text { (Australia) }\end{array}$ & $\begin{array}{l}\text { ED surveillance } \\
\text { children } 0-12 \\
\text { years, registry of } \\
\text { Adelaide dogs }\end{array}$ & & & $\begin{array}{l}\% \text { Attacks } v \% \text { dog } \\
\text { population } \\
\text { Bull terrier } 5.4 \text {, } \\
\text { German shepherd } \\
4.2 \text {, Doberman } 4.0 \text {, } \\
\text { Rottweiler } 2.6 \text {, blue } \\
\text { heeler } 2.4 \text {, collie } \\
1.2\end{array}$ & & & \\
\hline
\end{tabular}

households with dogs; over-representation of some breeds; male dogs; victim known to the dog; home location (child's or other home); dog's home.

\section{Discussion}

Few reliable rate data have been published for serious dog bite injuries, despite the availability of a specific $\mathrm{E}$ code. Where available, from the US, ${ }^{6-8}$ New Zealand, ${ }^{24}$ Canada (Laboratory Centre for Disease Control, Health Canada, analysis of Statistics Canada data, unpublished results), the UK, ${ }^{25}$ and Australia, ${ }^{9}$ rates appear to be similar for deaths and medically treated injuries. The Australian death and hospitalization rates for dog bite are 0.004 and 7.7 per
100 000, respectively. Direct comparison is complicated, however, by the variety of ways in which data were collected, including routine injury surveillance, case series studies based on treatment sources, dog bite reporting systems, and surveys.

The evidence suggests that the rate of dog ownership by households is similar for the US and Australia (35\% Melbourne, ${ }^{14} 42 \%$ Australia, ${ }^{1516}$ and $37 \% \mathrm{US}^{19}$ ).

Victorian data indicate no reduction in the rate of dog bite injury over the 11 years $1987-88$ to 1997-98, except for a significant reduction in hospitalizations for children aged $0-4$ years, since 1993. This reduction coincides with changes to the Domestic Animals (Feral and Nuisance) Act 1994, ${ }^{18}$ some enforcement by 
local governments, publication of dog bite statistics, and public information supplied by the media and child injury prevention organizations. The 1998 repeat of the 1992 Melbourne household survey indicated a reduction in dog ownership for households with young children. ${ }^{14}$

Further research and development is required to inform additional interventions. Standardized methods for reporting dog bite (and dog attack) are required. Dog bite injury should be routinely coded by the ICD 9 E code or the corresponding ICD10 code. A modification is required to the ICD coding system to specifically and separately record both bite and other dog attacks. The latter represent about $14 \%$ of all dog related injuries. ${ }^{10}$

Similarly, standardized methods for measuring and reporting dog populations are required. Good comparative data may contribute to the identification of international best practices for prevention. Reliable and practical methods for identifying dog breed need to be developed and validated, and the names of dog breeds should be clarified internationally. An atlas of common dog breeds and cross breeds is needed, including photographs with height and length measures. This would provide a reference against which panels of experts could identify breeds from photographs of dogs involved in attacks.

An alternative approach has been tried where survey data on the size of $\operatorname{dog}(\mathrm{s})$ is collected. This simplified information may prove more reliable than breed, and is possibly just as relevant as a risk factor.

Controlled studies of further risk and protective factors should be undertaken. Validated instruments will be required to determine breed, temperament, and level of training. Agreed terminology is also required for terms such as provoked/unprovoked attack and normal interaction with dogs. Rigorous evaluation studies should be conducted in association with future interventions. Studies are also required to identify barriers to the implementation of generally accepted preventive measures such as neutering of male dogs and avoidance of high risk dogs, particularly in households with young children.

\section{Implications for prevention}

Many published articles recommend preventive measures, including strict controls on high risk breeds, ${ }^{26}$ constraining measures such as leashing ${ }^{26}{ }^{27}$ "user pays" liability insurance, ${ }^{26}$ dog training ${ }^{21}{ }^{27}$ education for dog owners and families, ${ }^{2128-30}$ informed pet selection, ${ }^{19} 2830$ and enforcement of regulations. ${ }^{17}$ Bandow specifically recommends that all dogs should be socialized to accept children, that young children should never be left alone with a dog, and that owners be encouraged to inhibit biting behaviour. $^{21}$

Only two interventions were reported as effective. ${ }^{31}{ }^{32}$ The first was a police policy change from "bite-and-hold" (where the dog is trained to apply force, by mouth, as a technique to subdue individuals suspected for felony crimes) to the less injurious "find-and-bark"

\section{Key points}

- Highest rate of serious injury from dog bite is to children under 5 years of age.

- The all age hospitalisation rate for dog bite in Victoria, Australia showed no overall reduction over the 11 year period (1987-88 to $1997-98$ ).

- Average length of stay in hospital increases with the age of the victim, with almost $50 \%$ of those aged over 75 years being hospitalised for eight or more days.

- Emergency department surveillance data found that for children under 15 years, $66 \%$ of dog bite injuries occurred at their own home or at homes at which they were visitors, while $19 \%$ were in public places.

- Fifty one per cent of bites to children were to the face and scalp. Emergency department surveillance data also found that $38 \%$ of adult dog bite injuries occurred in public places.

- Identified risk factors include children, males, households with dogs, certain breeds, male dogs, home location, and leashed dogs.

- There is a need for responsible pet ownership which includes separating young children from dogs or at the very least, never leaving them alone with a dog as well as avoiding high risk dogs and neutering male dogs.

- Controlled investigation of risk, protective factors, and validated methods of breed identification are needed.

(where the dog is trained to find a perpetrator and bark to subdue, without force by mouth) for law enforcement involving dog teams operating in Los Angeles County. This intervention resulted in a decrease in the number of dog bite cases presenting to a jail ward emergency department from 639 (1988-91) to 66 (199295) and a decrease in the severity of injuries. ${ }^{31}$

Oswald, using a pre-test/post-test evaluation design, examined the effects of a potentially dangerous dog program in limiting the opportunity for these dogs to repeat biting behaviour. $^{32}$ In a random sample of 422 dogs pre-program and 372 post-program, $25 \%$ of dogs pre-program repeated biting behaviour within one year. Post-program, the repeat incidence was significantly reduced to $7 \%$ (p = $0.01)^{32}$

Most other interventions have not been evaluated, and debate about some measures, particularly breed specific legislation, continue in the literature and the media. ${ }^{212233}$

The Victorian studies reported here, together with the literature review, identify the need to reduce exposure by separating young children from dogs, particularly male dogs and certain breeds, particularly in the child's own home or in a home being visited. The Victorian experience suggests that well publicised strengthening of dog regulations can significantly reduce dog bite rates to young children. 
This research was funded by the Victorian Health Promotion Foundation and the Petcare Information and Advisory Service. Information and support were provided by Dr Jonica Newby, Associate Professor Simon Chapman (University of Sydney) and Stan Bordeaux (Research Centre for Injury Studies). Ruth Zupo (MUARC) assisted with editing and formatting the manuscript.

1 National Centre for Health Statistics. International classification of diseases, 9th revision, clinical modification (ICD-9$C M)$. Ann Arbor, Michigan: Commission on Professional and Hospital Activities, 1986

2 Watt G. Hospitalized injuries Victoria, Fuly 1987-fune 1993. Report No 67. Melbourne: Monash University Accident Research Centre, 1995

3 Watt G, Ozanne-Smith J. VISS goes electronic: second generation injury surveillance. Hazard 1996;26:1-6.

4 Australian Bureau of Statistics (ABS). Table 9. Estimated resident population by single year of age, Australia, States and Territories. June 2000 [cited 24 July 2000]. Population estimates available on internet: URL: pulation www.abs.gov.au/ausstats.

5 US Census Bureau. Historical National Population Estimates: fuly 1, 1900-fuly 1, 1999. April 2000 [cited 24 July 2000]. Fuly 1, 1900-fuly 1, 1999. April 2000 [cited 24 July 2000].
Population estimates available on internet: URL: http:// Population estimates available on internet: www.census.gov

6 Weiss HB, Friedman DI, Coben JH. Incidence of dog bite injuries treated in emergency departments. $\mathcal{F} A M A 1998$; 279:51-3.

7 Centers for Disease Control and Prevention. Dog bite related fatalities-United States, 1995-1996. MMWR Morb Mortal Wkly Rep 1997;46:463-7.

8 Sacks JJ, Sattin RW, Bonzo SE. Dog bite-related fatalities from 1979 through 1988. FAMA 1989;262:1489-92.

9 National Injury Surveillance Unit (NISU). Injury death Australia 1979-1998. Case numbers and rates per 100000 population by year of death registration, age and sex 1998 [cited 24 July 2000]. Rates and frequencies available on Internet: URL: http://www.nisu.flinders.edu.au/data/ internet:

10 Ashby K. Dog bites. Hazard 1996;26:7-13

11 Day L, Valuri G, Ozanne-Smith J. General practice injury surveillance in the Latrobe Valley. Report No 113. Melbourne: veillance in the Latrobe Valley. Report No 113. Melbourn

12 Flores J, Brown J, Mackenzie SG, et al. Innovative CHIRPP project focuses on dog bites. CHIRPP News 1997;11:3-7.

13 Australian Bureau of Statistics. Safety in the home, Melbourne, November 1992. Cat No 4387.2. Melbourne: ABS, 1993

14 Australian Bureau of Statistics. Safety in the home, Victoria, October 1998. Cat No 4387.2. Melbourne: ABS, 1999

15 McHarg M, Baldock C, Headey B, et al. National people and pets survey. Melbourne: Urban Animal Management Coalition, 1995. 16 Reark Research. Research report pet care industry statistics
1996. Prepared for Petcare Information and Advisory Service. Melbourne: Reark Research, 1997.
17 Ashby K, Routley V, Stathakis V. Enforcing legislative and regulatory injury prevention strategies. Hazard 1998;34:3-5. 18 Domestic (Feral and Nuisance) Animals Act 1994. Act No Domestic (Feral and Nuisance) An
81/1994. Victoria, Australia 1996.

19 Gershman KA, Sacks JJ, Wright JC. Which dogs bite? A case control study of risk factors. Pediatrics 1994;93:913-16.

20 Lockwood R, Rindy K. Are "pit bulls" different? An analysi of the pit bull terrier controversy. ANTHROZOÖS 1987;1: $2-8$.

21 Bandow JH. Will breed-specific legislation reduce dog bites? Can Vet f 1996;37:478-82.

22 Blackshaw JK. Dog bites and bull terriers. Aust Vet f 1991; 68:117-18.

23 Magazanik M. RSPCA seeks tough controls on pit bulls. The Sunday Age 19 May 1996.

24 Langley J. The incidence of dog bites in New Zealand. NZ Med f 1992;105:33-5.

25 Thomas HF, Voss S. A survey of dog bites in Salisbury. $f R$ Soc Health 1991;111:224-5.

26 Thompson PG. The public health impact of dog attacks in a major Australian city. Med F Aust 1997;167:129-32.

27 Podberscek AL, Blackshaw JK. The incidence of dog attack on children treated at a city hospital. Aust Vet $\mathcal{f}$ 1990;67:79-80.

28 Patrick GR, O'Rourke KM. Dog and cat bites: epidemiologic analyses suggest different prevention strategies. Public Health Rep 1998;113:252-7.

29 Podberscek AL, Blackshaw JK. Dog attacks on children: report from two major city hospitals. Aust Vet $\mathcal{F}$ 1991;68: $248-9$.

30 Sacks JJ, Kresnow M, Houston B. Dog bites: how big a problem? Inj Prev 1996;2:52-4.

31 Hutson HR, Anglin D, Pineda GV, et al. Law enforcement K-9 dog bites: injuries, complications and trends. Ann Emerg Med 1997;29:637-42.

32 Oswald $M$. Report on the Potentially Dangerous Dog Program: Multnomah County, Oregon. ANTHROZOÖS 1991;5:247-54.

33 South Australian Health Commission. Dog attacks. Injury Surveillance Monthly Bulletin 1990: No 29.

34 Szapkowski NM, Bonnett BN, Martin SW. An epidemioogical investigation into reported incidents of dog biting in the city of Guelph. Can Vet f 1989;30:937-42.

35 Schellart M. Rottweiler and Belgian Malinois sheepdog most likely to bite. Consumer Safety Institute (CSI) Injury Surveillance Exchange 1999;2:1-2.

36 Chang Y-F, McMahon JE, Hennon RN, et al. Dog bite incidence in the city of Pittsburgh: a capture-recapture approach. Am f Public Health 1997;87:1703-5.

37 Jarrett P. Which dogs bite? Arch Emerg Med 1991;8:33-5. 8 Shewell PC, Nancarrow JD. Dogs that bite. BMF 1997;303: 1512-13.

39 Avner JR, Baker MD. Dog bites in urban children. Pediatrics 1991;88:55-7.

40 Greenhalgh C, Cockington RA, Raftos J. An epidemiological survey of dog bites presenting to the emergency department of a children's hospital. F Paediatr Child Health 1991; 27:171-4. 